\title{
Pola Tata laksana Diare Akut di Beberapa Rumah Sakit Swasta di Jakarta; apakah sesuai dengan protokol WHO?
}

\author{
Pramita G. Dwipoerwantoro, Badriul Hegar, Pustika A. W. Witjaksono
}

Pada umumnya penyakit diare akut bersifat self limiting disease sehingga seringkali pasien tidak memerlukan pengobatan spesifik. Tata laksana diare akut dengan berbagai derajat dehidrasi telah dibakukan oleh WHO.

Tujuan: Penelitian ini bertujuan untuk menilai pola tata laksana diare akut di luar rumah sakit institusi pendidikan.

Metoda: Penelitian deskriptif yang dilakukan secara retrospektif di tiga rumah sakit swasta Jakarta sejak 1 Januari sampai 31 Maret 1999 pada 67 pasien diare akut yang dirawat, berumur 0-24 bulan.

Hasil: Didapatkan 37 (55\%) anak lelaki dan 30 (45\%) anak perempuan menderita diare akut, terdiri dari tanpa dehidrasi $6(9 \%)$ anak, dehidrasi ringan-sedang $52(78 \%)$ anak, dan dehidrasi berat $9(13 \%)$ anak. Proporsi rentang usia 0-6 bulan sebanyak 23 (34\%) anak, $>6-12$ bulan 28 (42\%), dan >12-24 bulan 16 (24\%). Jumlah pasien diare akut tanpa dan dengan dehidrasi ringan-sedang yang mendapat rehidrasi secara parenteral sebanyak $51(88 \%)$ anak dari 58 anak. Sedangkan sisanya menderita dehidrasi berat diberi cairan rehidrasi parenteral yang dibagi dalam 24 jam. Pada keseluruhan pasien rawat hanya $37(55 \%)$ anak yang mendapat cairan rehidrasi oral (oralit/Pedialyte). Penggunaan antibiotik didapatkan pada $55(82 \%)$ anak dan anti diare pada $32(48 \%)$ anak. Pemberian ASI hanya didapatkan pada 41 (61\%) anak, dan di antaranya pemberian ASI dilanjutkan pada $36(88 \%)$ anak, serta dihentikan pada $5(12 \%)$ anak; sedangkan 26 (39\%) anak sudah tidak mendapatkan ASI. Dari 51 anak yang menggunakan susu formula, didapatkan pemberian susu formula khusus pada $47(70 \%)$ anak dan pengenceran susu formula pada $2(3 \%)$ anak. Lama rawat rerata 3 hari, dengan kisaran 2 sampai 6 hari, dan 1 anak dirawat lebih dari 7 hari.

Kesimpulan: tata laksana diare akut di tiga rumah sakit swasta di Jakarta kurang sesuai dengan panduan/protabel WHO, tampak dari hasil pemakaian CRO hanya pada $50 \%$ pasien, antibiotik masih banyak dipakai (90\%), dan pemakaian susu formula khusus pada $70 \%$ anak. Sedangkan pemberian ASI diteruskan cukup baik, yaitu $88 \%$.

Kata kunci: diare akut, ASI, cairan rehidrasi oral (CRO), antibiotik, antidiare, anak

\footnotetext{
Alamat korespondensi:

dr. Pramita G. Dwipoerwantoro, SpA.

Divisi Gastrohepatologi Departemen Ilmu Kesehatan Anak FKUI/

RSCM.

Jl. Salemba 6, Jakarta 10430 (INDONESIA).

Telp/Fax: (021) 3915665. E-mail: pramitagd@yahoo.com
}

D iare masih merupakan penyebab utama kesakitan dan kematian anak terutama di negara berkembang, dengan prakiraan sekitar 1,5 milyar episod dan 1,5-2,5 juta kematian setiap tahun pada anak di bawah usia 5 tahun. ${ }^{1}$ Sekitar $85 \%$ kematian yang berhubungan dengan diare terjadi pada 2 tahun pertama kehidupan. ${ }^{2}$ Menurut laporan Departemen Kesehatan, di Indonesia setiap anak mengalami episod diare sebanyak 1,6-2 kali setahun. ${ }^{3}$ 
Faktor utama untuk mengurangi angka kematian akibat diare adalah program penggunaan cairan rehidrasi oral (CRO) secara meluas sebagai terapi dan pencegahan terhadap terjadinya dehidrasi. ${ }^{4} \mathrm{Hal}$ ini sesuai dengan anjuran American Academy of Pediatrics $(\mathrm{AAP})^{5}$ ataupun $\mathrm{WHO}^{6}$. Sesungguhnya CRO dianggap sebagai salah satu bentuk kemajuan di bidang kedokteran, ${ }^{7}$ karena bentuk sediaan yang sederhana, murah dan mudah didapat.

Adapun upaya tata laksana pasien diare di Indonesia telah dibakukan sejak tahun 1986, yaitu tidak hanya dengan cara membuat guideline (petunjuk) dan melatih petugas yang bekerja di sarana kesehatan saja, melainkan juga dengan cara memasukkan program atau paket Pendidikan Medik Pemberantasan Diare (PMPD) ke dalam kurikulum pendidikan Fakultas Kedokteran baik negeri maupun swasta. ${ }^{3}$ Penelitian ini dilakukan dengan tujuan untuk mengetahui pola tata laksana diare akut di rumah sakit swasta di luar institusi pendidikan.

\section{Subyek dan Metoda}

Penelitian dilakukan secara retrospektif di tiga rumah sakit swasta di Jakarta Selatan, lingkungan penduduk sekitar rumah sakit tersebut mempunyai kemiripan yaitu sangat heterogen terutama dari segi sosial ekonomi. Data berasal dari status pasien rawat inap berusia 0-24 bulan selama kurun waktu 3 bulan yaitu dari 1 Januari sampai dengan 31 Maret 1999, data dikumpulkan dengan cara mengisi kuesioner yang telah disiapkan. Sejumlah 67 anak diikutsertakan dalam penelitian ini.

Data yang dikumpulkan meliputi identitas lengkap pasien dan informasi seputar tata laksana diare akut setiap pasien yang dirawat yaitu derajat dehidrasi, pemberian cairan rehidrasi oral (CRO), indikasi penggunaan cairan parenteral dan cara pemberiannya, penggunaan antibiotik dan antidiare, penggunaan ASI dan susu formula, serta lama perawatan. Analisis data menggunakan program Epi Info 6.04b.

\section{Hasil}

Total pasien diare akut yang dirawat di ketiga rumah sakit swasta tersebut pada tanggal 1 Januari sampai dengan 31 Maret 1999 sebanyak 67 kasus, terdiri dari
37 (55\%) anak lelaki dan 30 (45\%) anak perempuan, dengan rentang usia 0-24 bulan. Usia kelompok umur 0-6 bulan 23 (34\%), >6-12 bulan 28 (42\%), dan >1224 bulan sebanyak $16(24 \%)$ anak. Derajat dehidrasi yang didapatkan adalah tanpa dehidrasi $6(9 \%)$, dehidrasi ringan-sedang 52 (78\%), dan dehidrasi berat $9(13 \%)$ anak (Tabel 1).

Tabel 1. Karakteristik Subyek

\begin{tabular}{ll}
\hline Parameter & $\begin{array}{l}\text { Jumlah(\%) } \\
\mathrm{n}=67\end{array}$ \\
\hline $\begin{array}{l}\text { Jenis kelamin } \\
\text { Lelaki } \\
\text { Perempuan } \\
\text { Usia (bulan) }\end{array}$ & $37(55)$ \\
$0-6$ & $30(45)$ \\
$>6-12$ & $23(34)$ \\
$>12-24$ & $28(42)$ \\
Derajat dehidrasi & $16(24)$ \\
Tanpa dehidrasi & $6(9)$ \\
ringan-sedang & $52(78)$ \\
berat & $9(13)$ \\
\hline
\end{tabular}

Dari 58 anak diare akut yang dirawat dengan dehidrasi ringan-sedang maupun tanpa dehidrasi, sebanyak $51(88 \%)$ anak mendapat rehidrasi secara parenteral. Sedangkan keseluruhan 9 anak yang menderita dehidrasi berat ditata laksana dengan cara pemberian cairan rehidrasi parenteral yang dibagi dalam 24 jam.

Pada Tabel 2 tampak pasien yang dirawat terbanyak adalah jenis kelamin lelaki dan menderita dehidrasi ringan-sedang yaitu pada 28 (42\%) anak. Akan tetapi sebaran jenis kelamin berdasarkan derajat dehidrasi tidak menunjukkan perbedaan yang bermakna secara tatistik $(\mathrm{p}>0,05)$. Sebaran kasus terbanyak pada kisaran usia $>6-12$ bulan dengan derajat dehidrasi ringan-sedang yaitu pada 24 (36\%) anak; sedangkan kasus dehidrasi berat terbanyak ditemukan pada kisaran usia 0-6 bulan yaitu sebanyak $6(9 \%)$ anak. Lama rawat rerata 3 hari, dengan kisaran 2 sampai 6 hari, dan hanya 1 anak dengan dehidrasi berat dirawat lebih dari 7 hari.

Pada keseluruhan pasien yang dirawat hanya 37 (55\%) anak dengan diare akut yang mendapat cairan rehidrasi oral (oralit/Pedialyte), dan di antaranya terbanyak digunakan pada kasus dehidrasi ringansedang sebanyak 31 (84\%) kasus. Secara statistik tidak 
Tabel 2. Sebaran derajat dehidrasi berdasarkan jenis kelamin, usia, hari rawat, pemberian cairan rehidrasi oral (CRO), ASI dan susu formula (SF)

\begin{tabular}{|c|c|c|c|c|c|c|}
\hline \multirow[t]{2}{*}{ Parameter } & \multicolumn{3}{|c|}{ Derajat Dehidrasi } & \multirow[b]{2}{*}{$\mathrm{X}^{2}$} & \multirow[b]{2}{*}{ df } & \multirow[b]{2}{*}{ nilai $\mathrm{p}$} \\
\hline & Tidak & Ringan-Sedang & Berat & & & \\
\hline \multicolumn{7}{|l|}{ Jenis Kelamin } \\
\hline Lelaki & 4 & 28 & 5 & & & \\
\hline Perempuan & 2 & 24 & 4 & $x^{2}=0,36$ & $\mathrm{df}=2$ & $\mathrm{p}=0,8361$ \\
\hline \multicolumn{7}{|l|}{ Usia (bulan) } \\
\hline $0-6$ & 1 & 16 & 6 & & & \\
\hline$>6-12$ & 2 & 24 & 1 & & & \\
\hline$>12-24$ & 2 & 11 & 2 & & & \\
\hline \multicolumn{7}{|l|}{ Hari rawat (hari) } \\
\hline 2 & 1 & 4 & 3 & & & \\
\hline 3 & 4 & 21 & 0 & & & \\
\hline 4 & 0 & 15 & 2 & & & \\
\hline 5 & 0 & 7 & 2 & & & \\
\hline 6 & 0 & 4 & 1 & & & \\
\hline$>7$ & 0 & 0 & 1 & & & \\
\hline \multicolumn{7}{|l|}{ Pemberian CRO } \\
\hline Ya & 2 & 31 & 4 & & & \\
\hline Tidak & 4 & 31 & 5 & $x^{2}=2,07$ & $\mathrm{df}=3$ & $\mathrm{p}=0,5582$ \\
\hline \multicolumn{7}{|l|}{ Pemberian ASI } \\
\hline Dilanjutkan & 3 & 25 & 8 & & & \\
\hline Dihentikan & 0 & 4 & 1 & & & \\
\hline \multicolumn{7}{|l|}{ Penggunaan SF } \\
\hline Dilanjutkan & 0 & 1 & 1 & $x^{2}=0,5$ & $\mathrm{df}=2$ & $\mathrm{p}=0,7805$ \\
\hline Diencerkan & 0 & 2 & 0 & & & \\
\hline SF husus & 5 & 25 & 5 & & & \\
\hline Tanpa SF khusus & 2 & 8 & 3 & & & \\
\hline
\end{tabular}

Keterangan* ${ }^{*} \mathrm{~F}=$ Susu Formula

tampak perbedaan bermakna $(\mathrm{p}>0,05)$ antara pasien yang mendapatkan $\mathrm{CRO}$ atau tanpa $\mathrm{CRO}$ berdasarkan derajat dehidrasi.

Pemberian ASI hanya didapatkan pada 41 (61\%) anak, dan di antaranya pemberian ASI dilanjutkan pada $36(88 \%)$ anak dan dihentikan pada $5(12 \%)$ anak; sedangkan 26 (39\%) anak sudah tidak mendapatkan ASI. Kasus diare akut dengan dehidrasi ringan sedang merupakan kelompok yang paling banyak menghentikan penggunaan ASI, diikuti dengan kasus dehidrasi berat. Secara statistik kasus diare akut yang melanjutkan pemberian ASI tidak berbeda secara bermakna ( $p>0,05)$ dengan yang menghentikan ASI.

Sebanyak $51(76 \%)$ anak dengan diare akut mengkonsumsi susu formula. Di antaranya pemberian susu formula pada saat diare diganti dengan susu formula khusus pada 47 (92\%) anak, pengenceran susu formula pada 2 (4\%) anak; sedangkan sisanya sebanyak 2 (4\%) anak dengan diare akut melanjutkan pemberian susu formulanya tanpa mengganti ataupun mengencerkannya.

Pada Gambar 1. tampak bahwa penggunaan antibiotik didapatkan pada $55(82 \%)$ anak dengan diare akut dan anti diare pada $32(48 \%)$ anak dengan diare akut, dan hal ini secara statistik berbeda bermakna $(\mathrm{p}<0,05)$.

\section{Diskusi}

Penelitian ini dilakukan sebagai penelitian pendahuluan untuk mengevaluasi tata laksana diare akut di luar institusi pendidikan. Pemilihan rentang usia 0-24 bulan sebagai kelompok yang diteliti selama 3 


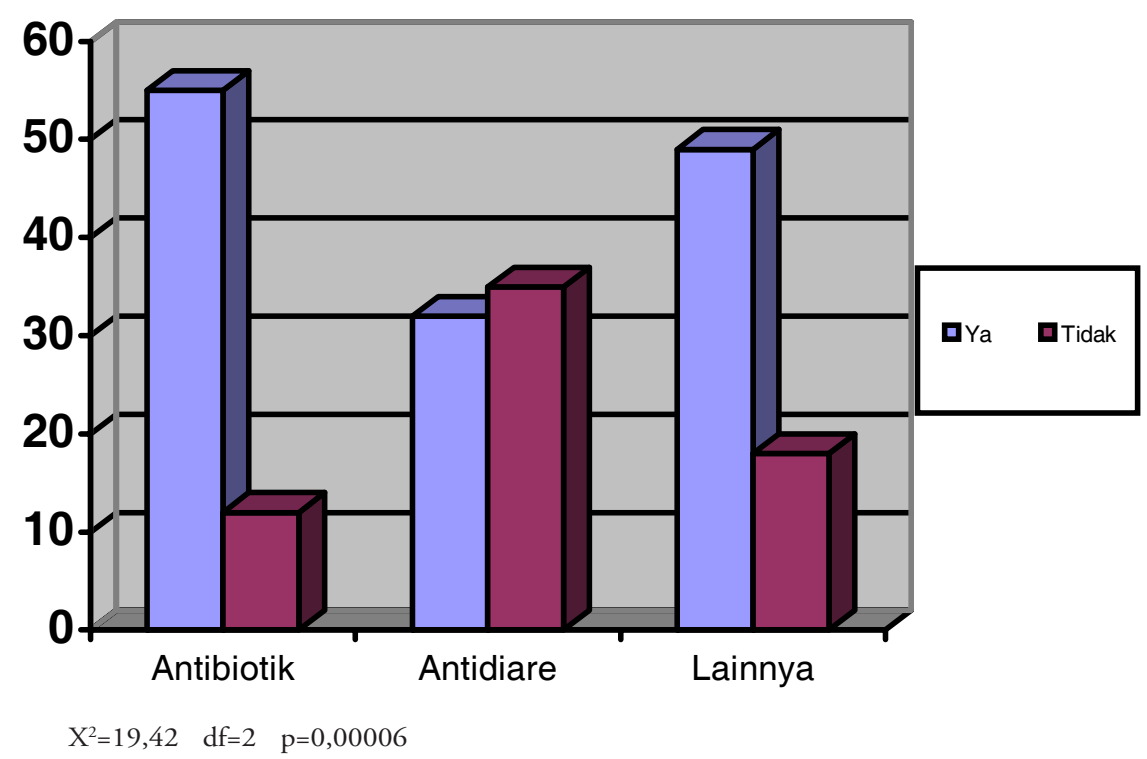

Gambar 1. Penggunaan Obat-obatan Berdasarkan Derajat Dehidrasi

bulan di ketiga rumah sakit swasta di Jakarta tersebut karena rentang usia 3-24 bulan merupakan rentang usia terbanyak terjadinya diare, bahkan tersering dengan manifestasi (dehidrasi) berat. ${ }^{8}$ Berbeda dengan penelitian Parashar $\mathrm{dkk},{ }^{8}$ ternyata pada penelitian ini derajat dehidrasi ringan-sedang merupakan indikasi rawat terbanyak pasien dengan diare akut (78\%) dengan lama rawat rerata 3 hari, sedangkan dehidrasi berat hanya terdapat pada13\% kasus saja. Cepatnya pasien dibawa ke rumah sakit pada saat awal diare kemungkinan merupakan salah satu faktor yang mempengaruhi perbedaan temuan tersebut.

Beberapa faktor yang memproteksi terjadinya infeksi Rotavirus pada bayi usia kurang dari 3 bulan di antaranya adalah pemberian ASI dan masih berperannya antibodi trans-plasenta. ${ }^{9,10}$ Praktek penghentian pemberian ASI pada kasus diare akut ternyata masih dijumpai walaupun jumlahnya tidak banyak (12\%). Protokol penanggulangan kasus diare akut pada anak menurut $\mathrm{WHO}^{6}$ maupun $\mathrm{AAP}^{5}$ sangat jelas untuk tetap melanjutkan pemberian ASI sejak upaya rehidrasi dimulai. Prilaku yang tidak sesuai ini sebaiknya dihindarkan, dan merupakan tanggung jawab bersama untuk tetap menganjurkan pemberian ASI, terutama pada bayi kecil, sebagai bagian dari upaya penanggulangan diare akut.
Pada penelitian ini dari keseluruhan pasien yang dirawat, ternyata hanya separuhnya (55\%) yang mendapatkan cairan rehidrasi oral (CRO). Rupanya manfaat CRO selain sebagai upaya terapi juga untuk mencegah terjadinya dehidrasi serta gangguan elektrolit, ${ }^{4-6}$ belum sepenuhnya dipahami dan dipraktekkan secara meluas. Terapi rehidrasi oral merupakan terapi pilihan dan sangat direkomendasikan untuk menggantikan cairan dan elektrolit yang hilang akibat diare pada anak dengan diare akut dehidrasi ringan-sedang. ${ }^{4-6}$ Namun ternyata mayoritas kasus (88\%) dengan diare akut tanpa dehidrasi dan dehidrasi ringansedang mendapat cairan rehidrasi parenteral tanpa ada keterangan yang mendukung adanya kegagalan terapi rehidrasi oral sebelumnya. Selain itu pada $13 \%$ kasus diare akut dengan dehidrasi berat ternyata cara pemberian cairan rehidrasi parenteral dibagi dalam 24 jam, tidak menggunakan cara yang telah dibakukan oleh WHO. ${ }^{3,6}$

Suatu meta analisis terhadap uji klinis mengenai penggunaan susu formula pada tata laksana diare akut menunjukkan bahwa anak dengan diare akut tanpa/dengan dehidrasi ringan-sedang yang di terapi sesuai dengan protokol WHO ternyata menunjukkan hasil yang baik dan tidak berbeda bermakna apakah dilanjutkan susu formulanya atau pun diganti dengan yang bebas laktosa. ${ }^{11}$ Penggunaan 
susu formula bebas laktosa pada penelitian Brown $\mathrm{dkk}^{11}$ lebih diindikasikan pada diare akut dehidrasi berat, dalam hal mengurangi kegagalan terapi. Pada penelitian ini ternyata sebanyak $76 \%$ kasus menggunakan susu formula, dan sebagian besar di antaranya (92\%) mengganti susu formulanya dengan kandungan yang rendah atau bebas laktosa. Hanya sekitar $4 \%$ yang melanjutkan susu formulanya. Tentunya hal ini akan membebani pasien terutama dalam hal biaya, karena penggunaan susu formula bebas laktosa tidak memberikan perbedaan yang bermakna dalam hal perbaikan klinis dibandingkan dengan susu formula mengandung laktosa.

Penggunaan antidiare dan antibiotik dalam penanganan kasus diare akut, pada penelitian ini, ternyata masih merupakan hal rutin di ketiga rumah sakit swasta di Jakarta. Portnoy ${ }^{12} \mathrm{dkk}$ pada penelitian 80 anak berusia 3 sampai 11 tahun yang dirawat di rumah sakit mendapatkan bahwa penggunaan suspensi kaolin-pektin dan cairan atropin-difenoksilat ternyata tidak bermanfaat dalam mengurangi frekuensi diare dan membuat konsistensi tinja lebih padat. Penggunaan antidiare yang telah diteliti dan ternyata terbukti bermanfaat di antaranya adalah terapi menggunakan probiotik (antara lain: lactobacillus) ${ }^{13}$ ataupun preparat inhibitor enkefalinase (racecadotril) $^{14}$ yang berfungsi sebagai antisekretori. Pengobatan menggunakan antibiotik pada umumnya tidak diperlukan pada semua kasus diare akut, karena sebagian besar penyebab diare akut adalah Rotavirus yang sifatnya self limited. ${ }^{15}$ Penggunaan antibiotik pada diare akut akan mengganggu ketahanan mikroflora usus sehingga akan menimbulkan gejala diare (antibiotic associated diarrhea), ${ }^{16,17}$ yang dapat berlanjut bahkan menjadi kronik. Berat ringannya diare yang terjadi akibat pemberian antibiotik bervariasi dari yang dapat sembuh dengan sendirinya dalam waktu singkat sampai manifestasi klinis yang berat disertai gangguan elektrolit, dehidrasi, nyeri perut, pseudomembranous colitis, toxic megacolon, bahkan kematian. ${ }^{17}$

\section{Kesimpulan}

Perlu digalakkan kembali tata laksana diare akut yang sesuai dengan standar baku WHO, untuk mengurangi over treatment yang sangat membebani pasien terutama dalam segi biaya. Selain untuk mengurangi angka kesakitan maupun kematian akibat diare akut yang melanjut menjadi kronik/ persisten dan malnutrisi.

\section{Daftar Pustaka}

1. Kosek M, Bern C, Guerrant RL. The global burden of diarrheal disease, as estimated from studies published between 1992 and 2000. Bull World Health Organ 2003; 81:197-204.

2. Griffin PM, Ryan CA, Nyaphisi M, Hargrett-Bean N, Waldman RJ, Blake PA. Risk factors for fatal diarrhea: a case-control study of African children. Am J Epidemiol 1988; 128:1322-9.

3. Departemen Kesehatan RI, Direktorat Jendral Pemberantasan Penyakit Menular dan Penyehatan Lingkungan Pemukiman. Buku Ajar Diare. Jakarta: Departemen Kesehatan RI; 1999.

4. Victora CG, Bryce J, Fontaine O, Monasch R. reducing deaths from diarrhea through oral rehydration therapy. Bull World Health Organ 2000; 78:1246-55.

5. American Academy of Pediatrics, Provisional Committee on Quality Improvement, Subcommittee on Acute Gastroenteritis. Practice Parameter. The management of acute gastroenteritis in young children. Pediatrics 1996; 97:424-35.

6. WHO. Management of the patient with diarrhea: programme for control of diarrhoeal disease. Geneva: WHO; 1992.

7. Water with sugar and salt [editorial]. Lancet 1978; 2:300-1.

8. Parashar UD, Holman RC, Clarke MJ, Bresee JS, Glass RI. Hospitalizations associated with rotavirus diarrhea in the United States, 1993 through 1995: surveillance based on the new ICD-9-CM rotavirus specific diagnostic code. J Infect Dis 1998; 177:137.

9. Bishop RF, Barnes GL,Cipriani E, Lund JS. Clinical immunity after neonatal rotavirus infection: a prospective longitudinal study in young children. $\mathrm{N}$ Engl J Med 1983; 309:72-6.

10. Newburg DS, Peterson JA, Ruiz-Palacios GM, Matson DO, Morrow AL, Shults J, et al. Role of human-milk lactadherin in protection against symptomatic rotavirus infection. Lancet 1998; 351:1160-4.

11. Brown KH, Peerson JM, Fontaine O. Use of nonhuman milks in the dietary management of young chil- 
Sari Pediatri, Vol. 6, No. 4, Maret 2005

dren with acute diarrhea: a meta-analysis of clinical trials. Pediatrics 1994; 93:17-27.

12. Portnoy BL, Dupont HL, Pruitt D, Abdo JA, Rodriguez. Antidiarrheal agents in the treatment of acute diarrhea in children. JAMA 1976; 236:844-8.

13. Van Niel CW, Feudtner C, Garrison MM, Christakis DA. Lactobacillus therapy for acute infectious diarrhea in children: a meta-analysis. Pediatrics 2002; 109:678-84.

14. Salazar-Lindo E, Santisteban-Ponce J, Chea-Woo E, Gutierrez M. Racecadotril in the treatment of acute watery diarrhea in children. N Engl J Med 2000; 343:463-7.

15. Pickering LK, Snyder JD. Gastroenteritis. In: Behrman RE, Kliegman RM, Arvin AM, editor. $15^{\text {th }}$ ed. Textbook of Pediatrics. Philadelphia: WB Saunders Co; 1996.

16. Sakata H, Fujita K, Yoshioka H. The effect of antimicrobial agents on fecal flora of children. Antimicrob Agents Chemother 1986; 29:225-9.

17. Bartlett JG. Antibiotic-associated diarrhea. Clin Infect Dis 1992 ; $15: 573-81$. 